\title{
The cystic fibrosis defect approached from different angles - new perspectives on the gene, the chloride channel, diagnosis and therapy*
}

\author{
D.J.J.Halley ${ }^{1}$, J.Bijman ${ }^{2}$, H.R.de.Jonge ${ }^{3}$, M.Sinaasappel ${ }^{4}$, H.J.Neijens ${ }^{4}$, and M.F.Niermeijer ${ }^{1}$ \\ Departments of ${ }^{1}$ Clinical Genetics, ${ }^{2}$ Cell Biology and Genetics, ${ }^{3}$ Biochemistry I, Erasmus University, P.O.Box 1738,3000 DR Rotterdam, \\ The Netherlands \\ ${ }^{4}$ Sophia Children's Hospital, P.O.Box 70029, 3000 LL Rotterdam, The Netherlands
}

Received November 30, 1989 / Accepted April 22, 1990

\begin{abstract}
The search for the basic defect in cystic fibrosis (CF) has reached a decisive stage since the recent identification of the responsible gene. Electrophysiological and biochemical research had defined the CF defect as a dysregulation of epithelial chloride channels. The putative protein product of the now identified gene shares properties with other known transport proteins, but it is not necessarily itself a chloride channel protein. Elucidation of the primary cellular defect will certainly have important aetiological and hopefully therapeutic implications. The identification of the major gene mutation already has significant consequences for genetic counselling and prenatal diagnosis. Heterozygote detection at the population level awaits identification of the probably heterogenous mutations on about $30 \%$ of the CF chromosomes. At present, about $50 \%$ of $\mathrm{CF}$ patients are homozygous for the recently identified major $\mathrm{CF}$ mutation.
\end{abstract}

Key words: Cystic fibrosis - Gene - Genetic counseling - Chloride channels

\section{Introduction}

Cystic fibrosis (CF) is the most frequent autosomal recessive disease among Caucasians with an incidence of

* Corresponding article on clinical aspects of cystic fibrosis by Neijens et al. will be published in the next issue of this journal, vol. 149, pp. 742-751 (1990)

Offprint requests to: D.J.J.Halley

Abbreviations: $\mathrm{ATP}=$ adenosine triphosphate; $\mathrm{cAMP}=$ cyclic adenosine monophosphate; $\mathrm{CF}=$ cystic fibrosis; CFTR $=$ cystic fibrosis transmembrane conductance regulator; cGMP = cyclic guanosine monophosphate; DAG = diacylglycerol; $\mathrm{MDR}=$ multidrug resistance; $\mathrm{PK}-\mathrm{A}=$ cyclic $\mathrm{AMP}$-dependent protein kinase; $\mathrm{PK}-\mathrm{C}=$ protein kinase $\mathrm{C}$; $\mathrm{PK}-\mathrm{G}=$ cyclic GMP-dependent protein kinase approximately $1: 2500$. Clinical manifestations include serious malfunctioning of the respiratory tract, as well as the pancreas and intestines. The elevated $\mathrm{NaCl}$ content of sweat in CF patients is used in diagnosis. Progress in the clinical management of the disease is the topic of the accompanying paper by Neijens et al. [47].

A disturbed function of exocrine gland epithelia is the common feature of the affected organs in CF patients. Unravelling epithelial anion transport mechanisms and their regulation is thought to be a major step towards the elucidation of the primary protein defect in $\mathrm{CF}$. The alternative approach in the search for the basic defect is molecular genetics. After the identification of closely linked DNA markers this has recently (1989) resulted in the identification of the CF gene and its most common mutation $[39,52,54]$. We will review the present state of knowledge on epithelial anion transport systems in relation to the postulated properties of the $\mathrm{CF}$ gene product.

The availability of closely linked polymorphic DNA markers already had considerable impact in genetic counselling and prenatal diagnosis. The clinical genetic implications of the detection of the major CF mutation will be discussed.

\section{CF: the gene and its genetic markers}

The search for the gene

When the primary protein defect in a genetic disease is still unknown, the first requirement for tracing the responsible gene is chromosomal localisation. The demonstration of linkage of the $\mathrm{CF}$ mutation to protein and DNA markers in 1985 led to the assignment of the CF locus to chromosome $7 \mathrm{q} 31$ [21, 42, 58, 60,61]. The Met oncogene locus and the anonymous DNA marker J3.11, which are about 1500 kilobases apart, were identified as the probable borders of the CF gene-containing region $[2,20,49]$. 
Molecular genetic research employed strategies to isolate fragments from "hypomethylated CpG islands" (sequences that are often associated with genes) and saturation mapping to find closer marker sequences at $7 \mathrm{q} 31$, which narrowed the "CF region" to an area of approximately 350-500 kilobases [23, 25, 36, 53]. The application of chromosome walking and jumping techniques led to the identification of a gene sequence that is expressed in the epithelia involved in CF $[52,54]$. The predicted protein structure of the gene product shows properties of a membrane protein with a transport function, possibly but not necessarily a chloride channel [52]. In the absence of a confirmatory test at the protein level, evidence that this cystic fibrosis transmembrane conductance regulator (CFTR) gene is in fact the CF gene rests on genetic arguments.

The search for the gene had previously produced a set of very closely linked polymorphic DNA markers, some of which are in strong linkage disequilibrium with CF $[22,25,53]$. The preferential cosegregation of a defective CF gene with a specific haplotype of polymorphic alleles has led to the estimate that over $85 \%$ of $\mathrm{CF}$ chromosomes of North West European origin may carry the same mutation [22]. Indications for the occurrence of more than one mutation were derived from linkage disequilibrium comparisons between different ethnic groups $[12,24,45]$ and between patients with well defined clinical differences, such as pancreatic involvement versus pancreatic sufficiency $[18,38]$.

Kerem et al. [39] identified a three base pair deletion in a CF counterpart of the normal CFTR gene. This deletion was subsequently found on $70 \%$ of CF chromosomes, in other words about half of the CF patients are homozygous for the three base pair deletion. The deletion was almost exclusively associated with the haplotype that shows the highest linkage disequilibrium with $\mathrm{CF}$ and it was never found on normal chromosomes. These data provide strong evidence that the CFTR gene is the gene that is involved in CF and that the three base pair deletion is its most common mutation. This major mutation is found more often among patients that suffer from pancreatic insufficiency than among the pancreatic sufficient group [39]. The number of mutations that remain to be identified is estimated to be greater than seven [39].

\section{Clinical genetic applications}

The available polymorphic markers have also played a significant role in genetic counselling and prenatal diagnosis. For nearly all couples with a 1:4 recurrence risk seeking prenatal monitoring of the next pregnancy a fully informative pattern of polymorphic alleles may be established, provided that DNA from an index patient is available. The ensuing reliability of prenatal prediction is over $99 \%$ in the majority of cases, as some of the most informative markers map at a genetic distance of only $\pm 0.1 \mathrm{cM}(0.1 \%$ chance of recombination) from the $\mathrm{CF}$ mutation [27]. An important aspect is that DNA analysis allows 1st trimester diagnosis after chorionic villus sampling, while the alternative test, the assay of fetal micro- villar enzymes measuring a secondary phenomenon of the disease in amniotic fluid, does not reach maximum reliability until the 17 th- 18 th week of pregnancy $[9,11$, 46]. The result of a prenatal DNA test is usually available about 1 week after chorionic villus sampling, when conventional methods of restriction enzyme digestion, Southern blotting and hybridisation with radioactively labelled DNA probes are applied. When informativity is found for those polymorphisms that are suitable for direct detection after DNA amplification a same-day diagnosis is possible [28, 48, 62].

The obvious limitation of linkage analysis is that its application is restricted to prenatal diagnosis and carrier identification within families, where a DNA sample of an index patient is available. In other words, linkage analysis is dependent on marker haplotype information from the propositus' DNA and the results are valid only within the same family.

The identification of the major CF mutation, for which about $50 \%$ of the patients are homozygous, implies that mutation analysis may now replace linkage analysis in about $50 \%$ of the pregnancies at a $1: 4$ risk of CF [32]. The requirement is that both parents show heterozygosity for the deletion. In these cases, early prenatal diagnosis of CF becomes index patient-independent and will also be accessible to parents whose only affected child has deceased in the absence of material to study linkage phase. The deletion can be analysed by amplification of the relevant region of the gene and detection of the nor$\mathrm{mal}$ and deleted alleles with specific oligonucleotides $[32,39]$.

The possibilities for carrier detection are still different for individuals with and without a family history of CF. In principle, the carrier status of close relatives of CF patients can be established with the same restrictions that apply to prenatal diagnosis. Mutation analysis may substitute for linkage studies when the individual has an affected sib who is homozygous for the deletion or an unaffected (carrier) sib who is heterozygous for the deletion.

When there is no family history of $\mathrm{CF}$, members of a Caucasian population have an average risk of $1: 25$ of being a CF carrier. Haplotyping for those markers that are in linkage disequilibrium with $\mathrm{CF}$ has been applied for risk modification. Haplotypes may be discriminated that are at high or at low risk of being associated with CF. The predictive value of haplotype analysis with markers like XV2c, KM19 and CS-7 may significantly alter the population risk, to an upper limit of about $1: 5$ and a lower limit of about 1:300 [3,26]. The first option now would be to test for the presence of the three base pair deletion. About $70 \%$ of carriers would be identified in this way, equivalent to $1: 35$ members of a Caucasian population. When an individual is shown to be free of the deletion, studying markers at linkage disequilibrium with CF may be of limited value, because the observed disequilibrium largely coincides with the presence of the three base pair deletion and because the remaining defects are obviously much more heterogeneous.

The now available knowledge of the CF gene sequence provides the possibility to eventually trace all mutations 


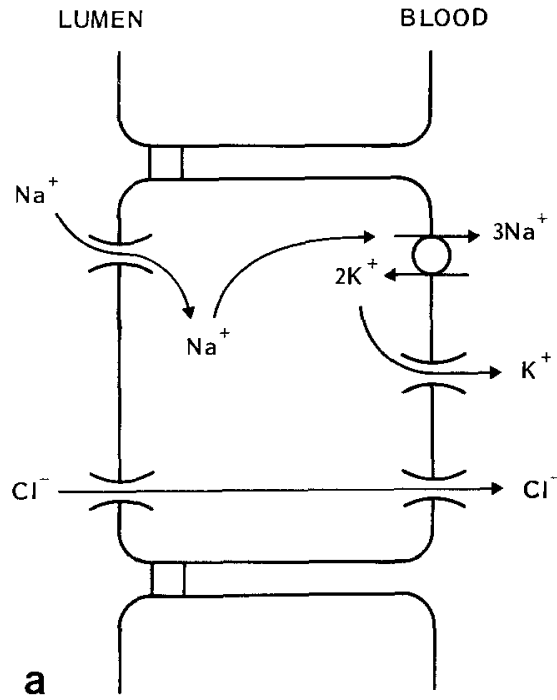

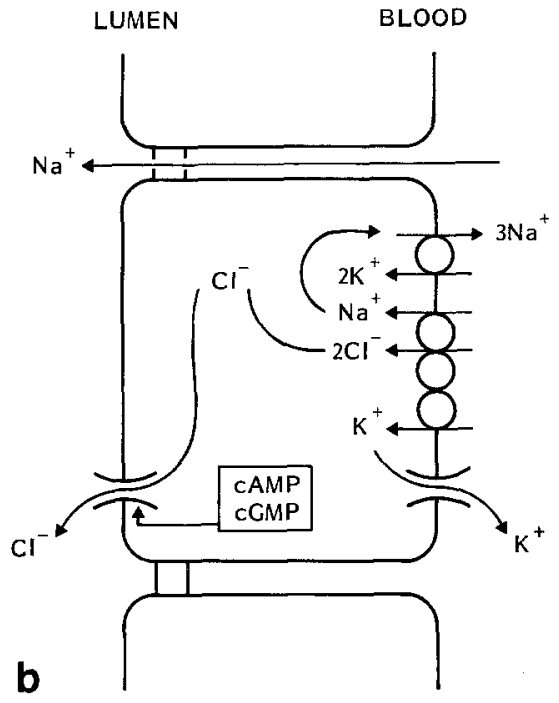

Fig. 1. Model of cells that reabsorb $\mathrm{NaCl}$ (a) or secrete $\mathrm{NaCl}(\mathbf{b})$. The cells share an ATP dependent $3 \mathrm{Na} / 2 \mathrm{~K}$-pump protein, which constitutes the primary driving force for sodium and chloride movement, and a chloride channel protein. In (a) sodium is driven into the cell, down its electrochemical gradient through an apical sodium channel protein, followed by chloride. In (b) a basolateral $\mathrm{Na}-\mathrm{K}-2 \mathrm{Cl}$ symport protein, energised by the sodium and potassium gradient that is set up by the $3 \mathrm{Na} / 2 \mathrm{~K}$ pump, concentrates chloride ions above electrochemical equilibrium in the cytosol of the cell. When in this cell the apical chloride channel is activated, chloride ions will flow out of the cell followed by sodium ions through the paracellular junction pathway [31] that cause CF. Identification of all CF mutations would allow prenatal diagnosis without restrictions as well as screening for $\mathrm{CF}$ carriers without remaining uncertainties.

The next sections review the present knowledge on the presumed cellular site that is affected by the CF mutations, and the possible roles of the normal and deleted CFTR gene products.

\section{Disturbed chloride transport in cystic fibrosis epithelia}

$\mathrm{CF}$ is characterised by meconium in the gastro-intestinal tract, obstruction of the airways and malfunction of the pancreas. The dehydrated obstructions in these CF organs could result from a decreased secretion or increased reabsorption of fluid and electrolytes. This hypothesis will be discussed in this section.

Secretion or reabsorption of water in the organs involved in $\mathrm{CF}$ results from the transport of salt, mainly sodium and chloride ions, across the epithelial cells (Fig.1) that line the outer border of these organs. When ducts of normal and CF sweat glands are studied with electrophysiological methods it appears that the transepithelial potential difference is elevated in the CF duct $[6,50,51]$. This observation, combined with the finding that the $\mathrm{NaCl}$ concentration in the sweat of CF patients is elevated, provides firm evidence for a decreased chloride permeability of the CF sweat duct [5], apparently due to a latency of chloride channel activation (Fig. 1). Alternatively, the increased potential difference in CF nasal epithelium [40] could result from a combined increase in reabsorption of sodium ions e.g. CF nasal polyp cells have an increased number of sodium channel proteins or $3 \mathrm{Na}-2 \mathrm{~K}$-ATPase transport proteins and decreased reabsorption of chloride ions [41]. At present, the most detailed studies have been focussed on the defect in chloride channel activation.

An elegant technique to study chloride channel regulation in intact cells and in isolated membrane patches is patch-clamp analysis of single ion channels [33]. A patch

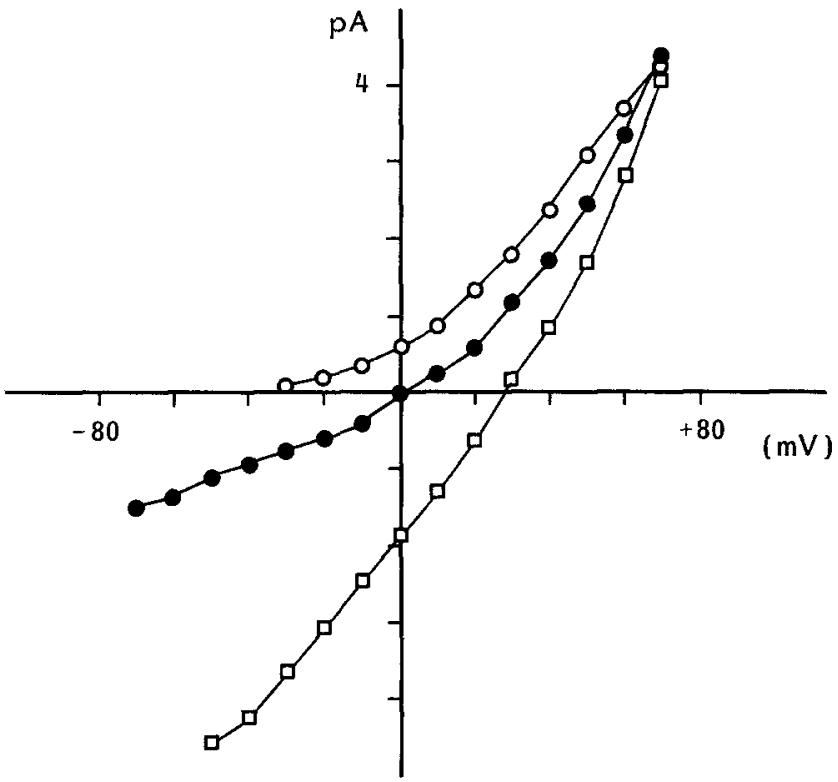

Fig. 2. Current to voltage relationship of the chloride channel with different anion composition of the bath (b) and pipette (p) Ringer solution. $\longrightarrow, 150 \mathrm{mM} \mathrm{Cl}^{-} \mathrm{b} / 150 \mathrm{mM} \mathrm{Cl}{ }_{\mathrm{p}}^{-} ; \mathrm{O}-15 \mathrm{mM}$ $\mathrm{Cl}^{-}{ }_{\mathrm{b}} / 150 \mathrm{mM \textrm {Cl } _ { \mathrm { p } } ^ { - }} ; \square \longrightarrow \square, 400 \mathrm{mM \textrm {Cl } _ { \mathrm { b } }} / 150 \mathrm{mM \textrm {Cl } ^ { - } \mathrm { p }}$

of membrane is sealed onto the tip of a micropipette while the current through the innate channels is measured by applying a clamp potential across the membrane. The channel activity and its regulation can be studied in on-cell patches and excised, cell-free, patches. Furthermore, a given channel can be characterised utilising different ion gradients (Fig. 2) across the membrane. Patch clamp analysis has shown that several chloride channels with distinct characteristics are present in epithelial cells [57].

The channel of interest in CF cells appears to be a $30-50 \mathrm{pS}$ conductance chloride channel that is voltage rectifying. A characteristic observed only in the excised patch condition is the voltage activation phenomenon. Apparently, the chloride channel remains silent in a cell- 
free patch when the clamp potential is held at physiological value. However, the application of depolarising voltages leads to rapid channel activation in normal tissue, even in the absence of physiological activating signals. Most importantly, depolarising conditions unmasked "latent" chloride channels in CF tissue. These channels display characteristics similar to the voltage activated channels of normal tissue $[10,43,56]$, which argues strongly against a mutation in the conductive part of the channel or a channel recruitment defect in CF. Instead, the $\mathrm{CF}$ defect is most plausibly located in a regulatory component as part of the channel gating mechanism operating under physiological conditions in the intact cell, as will be delineated in the section regulation.

\section{Regulation of chloride channels: a search for the molecular basis of chloride channel dysregulation in cystic fibrosis}

Up- and down-regulation of $\mathrm{Cl}^{-}$channel activity by neurotransmitters and hormones is triggered in most cells through hormone-induced changes at the level of intracellular second messengers, such as cyclic nucleotides, calcium $\left(\mathrm{Ca}^{2+}\right)$, and diacylglycerol (DAG) [32, 33]. Hypothetically, cyclic nucleotide and $\mathrm{Ca}^{2+}$ regulation of ion channels may occur through:

(1) a direct interaction with an allosteric modifier site on the channel protein itself;

(2) channel recruitment through fusion of channel-containing intracellular membrane vesicles with the plasma membrane; and

(3) phosphorylation of a regulatory (sub)unit of the $\mathrm{Cl}^{-}$ channel by cyclic adenosine monophosphate (cAMP)-, cyclic guanosine monophosphate (cGMP)- or $\mathrm{Ca}^{2+} / \mathrm{DAG}-$ dependent protein kinases.

\section{Cyclic nucleotide-dependent protein kinases}

Direct evidence in favour of the phosphorylation model has been obtained recently in patch clamp studies of excised membrane patches from human tracheal cells [43, 56], lymphocytes [10] and colon carcinoma cells [17]. Exposure of the inside-out patch to the catalytic subunit of cAMP-dependent protein kinase (PK-A) and adenosine triphosphate (ATP) under conditions preventing voltage activation resulted in phosphorylation-induced activation of the $\mathrm{Cl}^{-}$channel that could be reversed by an endogenous protein phosphatase. In contrast, the addition of cyclic nucleotides and/or calcium alone was unable to promote $\mathrm{Cl}^{-}$channel activation $[17,56]$.

Most importantly, the addition of PK-A plus ATP to a CF patch failed to activate its $\mathrm{Cl}^{-}$channel, which could subsequently be unmasked by voltage activation $[10,43$, 56]. These experiments have narrowed down the search for the CF defect to a step in the cAMP activation of the $\mathrm{Cl}^{-}$channel distal to PK-A but upstream of the conductive (sub)unit of the channel.

The search for a membrane phosphoprotein serving as a key regulator of the $\mathrm{Cl}^{-}$channel has been stimulated by the discovery of a unique enzyme with cGMP-dependent protein kinase activity (PK-G). This enzyme has so far been found exclusively in the intestinal brush border and is capable of activating the intestinal $\mathrm{Cl}^{-}$channel in response to cGMP itself or to a specific activator of the cGMP-generating enzyme guanylate cyclase, i.e. heatstable Escherichia coli enterotoxin [13, 14]. Measurements of $\mathrm{Cl}^{-}$secretion in intestine from CF patients with meconium ileus have demonstrated a defect in cGMP activation of the $\mathrm{Cl}^{-}$channel at a site distal to PK-G $[1,4,15]$.

\section{$\mathrm{Ca}^{2+} / D A G$ signals}

Less information is available about the molecular mechanisms by which $\mathrm{Ca}^{2+}$ and DAG modulate the activity of epithelial $\mathrm{Cl}^{-}$channels. Both signals are generated by a variety of stimuli, such as acetylcholine, bradykinin and histamine. The first step is the activation of phospholipase $\mathrm{C}$, which catalyses the release of both inositoltrisphosphate, a $\mathrm{Ca}^{2+}$-mobilising signal, and DAG from inositolphospholipids in the plasma membrane. $\mathrm{Ca}^{2+}$ signals may activate the $\mathrm{Cl}^{-}$channel either through coupling to a high-affinity $\mathrm{Ca}^{2+}$ binding protein (e.g. the $\mathrm{CF}$ antigen [19]?), which serves as a dissociable subunit of the channel or through a $\mathrm{Ca}^{2+}$-dependent protein kinase catalysing channel phosphorylation. DAG acts as a protein kinase $\mathrm{C}$ (PK-C) activator. Experiments with enterocytes and with airway epithelial membrane patches have shown that PK-C may play a double role, as epithelial $\mathrm{Cl}^{-}$channels may both be up- and down-regulated $[17,44]$. Activators of PK-C like phorbolesters are capable of activating the channel in the absence of other stimuli, but promote a rapid closure of the channel following its preactivation by $\mathrm{Ca}^{2+}$ or cyclic nucleotides [17]. These results can be explained by postulating a second phosphorylation site on the channel or on a channel regulator that acts as an inhibitory modifier ( $\mathrm{P} 2$ in Fig. 3) and is recognised by PK-C solely if the stimulatory site is prephosphorylated by PK-A, PK-G, or PK-C.

The effect of $\mathrm{Ca}^{2+}$ and $\mathrm{PK}-\mathrm{C}$ on $\mathrm{Cl}^{-}$channels in $\mathrm{CF}$ tissues is not uniform. The $\mathrm{Ca}^{2+}$ activation of the channel is defective in CF sweat gland duct and intestine, but remains unaffected in CF trachea and sweat gland coil, whereas PK-C fails to activate $\mathrm{Cl}^{-}$channels in most $\mathrm{CF}$ tissues, such as trachea, sweat gland duct and intestine $[15,16,35,44,63]$. The molecular basis for the different sensitivities of the $\mathrm{Cl}^{-}$channel to $\mathrm{Ca}^{2+} / \mathrm{DAG}$ signalling (i.e. cholinergic stimulation) in various $\mathrm{CF}$ epithelia is not yet elucidated. Interestingly, voltage activation of $\mathrm{Cl}^{-}$channels in excised patches from $\mathrm{CF}$ tracheal cells could still be reversed by PK-C in the presence of $\mathrm{Ca}^{2+}$, indicating that the inhibitory phosphorylation site (P2) functions normally in CF [44].

The data summarised here allow the following conclusions:

1. Both the secretory $\mathrm{Cl}^{-}$channel in $\mathrm{CF}$ intestine and the absorptive $\mathrm{Cl}^{-}$channel in CF sweat duct are insensitive to all (patho)physiological activators known so far and can only be activated artificially by voltage depolari- 


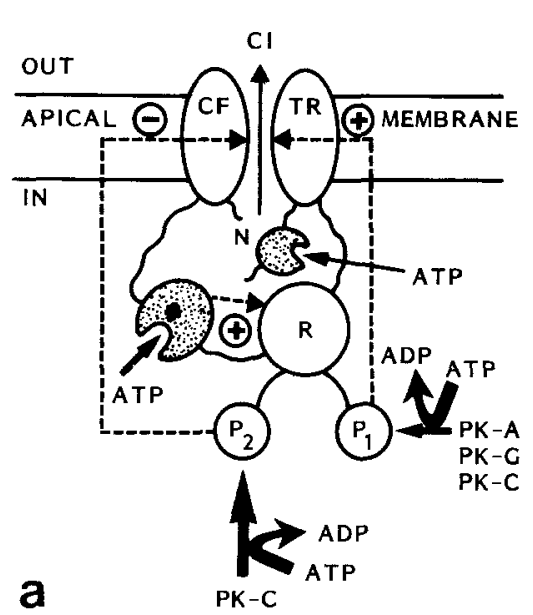

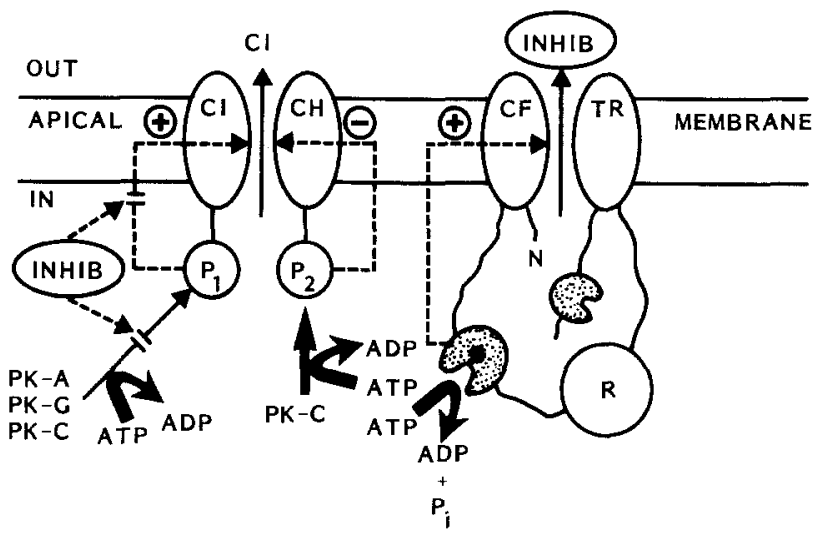

b
Fig. 3. Hypothetical models indicating possible relationships between the CF gene product CFTR and epithelial chloride channels. a CFTR (predicted structure modified from [52]) is depicted as a $\mathrm{Cl}^{-}$conducting transmembrane protein containing additional sites for ATP binding (dotted area) and phosphorylation (regulatory domain $R$ ). Phosphorylation of CFTR at $P 1$ activates the channel, whereas phosphorylation at $P 2$ inactivates the channel. When phenylalanine is deleted from an ATP binding domain, its necessary interaction with the regulatory domain is affected. b CFTR is depicted as a pump protein, which influences the activity of the $\mathrm{Cl}^{-}$channel $(\mathrm{Cl} \mathrm{CH})$ by adjusting the level of a specific $\mathrm{Cl}^{-}$channel inhibitor (INHIB). The deletion of phenylalanine from an ATP binding domain of CFTR impairs ATP-driven extrusion of the channel inhibitor, thereby resulting in a (reversible) blockade of the channel. The $\mathrm{Cl}^{-}$conducting domain remains unaffected, in agreement with the observed voltage activation of the channel in excised membrane patches. The asterisk shows the major mutation site in cystic fibrosis

sation. The apparent protective effect of the CF mutation against secretory diarrhoea, e.g. cholera, could possibly explain the high incidence of $\mathrm{CF}$ in the Caucasian population [7].

2. The insensitivity of the $\mathrm{Cl}^{-}$channel in $\mathrm{CF}$ towards multiple independent signals (cAMP, cGMP, DAG; $\mathrm{Ca}^{2+}$ in some tissues) is indicative for either: (1) a defect in a common regulatory step distal to PK-A, PK-G and PK-C, e.g. a functionally important domain or subunit of the $\mathrm{Cl}^{-}$channel (Fig. 3A); (2) the accumulation of an (as yet unidentified) intracellular inhibitor of $\mathrm{Cl}^{-}$channel phosphorylation and function (Fig. 3B), or (3) hyperactivation of an enzyme involved in down-regulation of the channel, e.g. PK-C or a protein phosphatase. The latter model would explain some additional abnormalities in other cellular functions controlled by the same regulatory enzymes, such as the upregulation of $\mathrm{Na}^{+}$channels in CF trachea [8] and the induction of apical $\mathrm{K}^{+}$channels in $\mathrm{CF}$ intestine $[15,16]$. However, this model has become less plausible since the recent identification of the CF gene, suggesting that the $\mathrm{CF}$ gene product bears no resemblance to PK-C or protein phosphatases and is also unlikely to function as a regulatory protein of kinases or phosphatases.

\section{Identification of the $\mathrm{CF}$ gene: does it encode a chloride channel protein?}

The putative CF gene product CFTR shows considerable homology with a family of ATP-dependent transport proteins that includes the mammalian multidrug resistance P-glycoprotein (MDR) [52]. The now identified major $\mathrm{CF}$ mutation accounts for about $70 \%$ of the defects. This three base pair deletion results in an in-frame deletion of a phenylalanine residue from one of the putative ATP-binding domains in CFTR [52], which apparently causes chloride channel dysfunction. However, a crucial role of an ATP binding site is a typical feature of pump proteins rather than of ion channels. On the other hand, charged amino acids occur in the membrane-spanning part of the protein and a unique cytoplasmic domain carries multiple potential phosphorylation sites for PK-A and PK-C [52] (Fig. 3). On the basis of the latter characteristics CFTR may still be a chloride channel protein.

In this respect it is interesting to note that ATP has always been included in excised patch experiments with $\mathrm{PK}-\mathrm{A}$ and PK-C. It was thought to be required solely as a co-substrate for these protein kinases, but now it seems that ATP may also be a ligand for the chloride channel itself (Fig. 3) [10, 35, 43, 44, 56, 57].

If CFTR were the chloride channel, it is relevant to mention that the epithelial channel-mediated transport of chloride ions follows their electrochemical gradient. Thus, transport per se does not require energy. Therefore, the ATP binding sites in CFTR may very well serve additional functions such as the allosteric modification of channel conformation or the (auto)phosphorylation of the inhibitory phosphorylation site ( $\mathrm{P} 2$ in Fig. 3) that keeps the channel in a closed state in the absence of stimulatory signals.

Alternatively, the observed sequence similarity between the MDR and the CFTR genes may be accompanied by a direct functional similarity between their products. When cancer cells become resistant to a number of unrelated drugs simultaneously, this is due to the MDR gene-encoded P-glycoprotein, which acts as a pump protein that removes toxins from the cells [37]. CFTR 
might act as a pump to adjust the intracellular level of chloride channel-inhibitors by mediating their transport across the epithelial membrane (Fig. 3b).

These considerations regarding the function of CFTR are based on its presumed localisation in the plasma membrane. Until alternative cellular localisations have been excluded, such as the endoplasmic reticulum or Golgi membranes, it may even be conceivable that CFTR plays a role in the post-translational modification or membrane insertion of the chloride channel protein.

At present, any prediction about the function of CFTR is based entirely on DNA sequence homologies with genes that encode proteins with known transport functions. Speculations still have to be substantiated by gene expression studies, protein purification and reconstitution experiments. At this stage it would not be justified to localise the CF defect in epithelial chloride channels. In any case, the study of CFTR structure and function is likely to provide important new insights into the molecular properties and regulation of epithelial anion channels in general. Since the CF defect apparently conveys protection from secretory diarrhoea it would be conceivable that specific chloride channel inhibitors may find future application as antidiarrhoeal agents. On the other hand, these studies may trigger the development of a chloride channel agonist capable of correcting or bypassing the defect in CF.

\section{Concluding remarks}

The identification of the CFTR gene is expected to have significant clinical consequences hopefully including new therapeutic perspectives.

At the diagnostic level the analysis of the three base pair deletion will replace linkage analysis to a certain extent. Deletion analysis introduces the possibility of early prenatal diagnosis for $50 \%$ of the couples who lost their only affected child, i.e. when both parents are heterozygous for the same deletion. In the remaining cases 1st trimester diagnosis using closely linked markers will still rely on marker information from index patient and parents.

The three base pair deletion detects about $70 \%$ of CF carriers. Already the debate has started whether or not this is sufficient to start screening for $\mathrm{CF}$ carriers in the population [30, 52]. As discussed above, testing persons without a family history of CF by deletion analysis would identify about 1:35 of them as carriers. For the others the remaining risk of being a carrier would be difficult to establish. The use of a statistical approach based on linkage disequilibrium will be hampered by the expected heterogeneity in the other mutations that cause CF. An unequivocal carrier test awaits the identification of the other gene defects. To this end the investigators who identified the gene and the Cystic Fibrosis Foundation (USA) have initiated a consortium of laboratories, which have been involved in CF research and/or diagnostics (L-C Tsui, personal communication). The aim is to distribute experimental materials and protocols and to collect results and population data, which would regulate the search for the other mutations in the most efficient way.

The identification of the CFTR gene is also a major step towards unravelling the pathophysiology of $\mathrm{CF}$. Subsequent studies should reveal the role of the normal CFTR gene product in chloride channel function. The next important question is how the deletion of a single amino acid in a nucleotide binding domain affects chloride transport. As was outlined above a functional impairment of the protein may be envisaged, even though the missing phenylalanine does not belong to the supposedly crucial amino acids for ATP binding [34]. Alternatively, the deletion of a phenylalanine may prevent CFTR to reach its site of action, analogous to the functionally unaffected products of the alpha-1-antitrypsin deficiency alleles $Z$ and Mmalton. The $Z$ variant contains a single amino acid substitution and Mmalton has an inframe deletion of phenylalanine. Apparently, both mutations prevent normal processing and result in impaired secretion and intracellular accumulation of alpha-1-antitrypsin [29]. Possibly, the deletion of phenylalanine from CFTR would represent a membrane-insertion defect.

The feasibility of curative protein therapy in CF patients will be strongly dependent on the nature and the cellular site of the defect. The identification of the CFTR gene will enable molecular biologists, electrophysiologists and biochemists to combine their efforts in finding the basic CF defect. The search for other mutations is likely to reveal additional crucial regions of the gene. It is to be expected that some of the answers will be generated by correction studies, experimental designs aimed at restoration of the mutant phenotype in CF epithelial cells through expression of the normal gene sequence or the administration of the normal gene product. Recently, immortalised nasal polyp epithelial cell lines from a CF patient were described, which had retained the mutant phenotype in patch clamp studies [55] and which were shown to be homozygous for the phenylalanine deletion (unpublished observation). These cell lines seem suitable targets for correction studies and may eventually even serve as in vitro model systems for (gene) therapy in $\mathrm{CF}$.

The concept of gene therapy of genetic diseases is still theoretical. However, the progress towards gene therapy of diseases that might be cured through correction of haemopoietic stem cells using modified retroviral vectors has been impressive [59]. Experiments carried out in vitro and later on in animal models should provide the conditions to reach and stably transfect the target tissues in CF.

At present, these considerations are necessarily speculative. There is, however, no doubt that the search for the basic $\mathrm{CF}$ defect has been given a new direction after the identification of the responsible gene.

\section{References}

1. Baxter PS, Goldhill J, Hardcastle J, Hardcastle PT, Taylor CJ (1988) Accounting for cystic fibrosis. Nature 335:211

2. Beaudet A, Bowcock A, Buchwald M, Cavalli-Sforza L, Farrall M, King M-C, Klinger K, Lalouel J-M, Naylor S, Ott J, 
Tsui L-C, Wainwright B, Watkins P, White R, Williamson R (1986) Linkage of cystic fibrosis to tightly linked DNA markers: joint report from a collaborative study. Am J Hum Genet 69:681-693

3. Beaudet A, Feldman GL, Fernbach SD, Buffone GJ, O'Brien WE (1989) Linkage disequilibrium, cystic fibrosis, and genetic counseling. Am J Hum Genet 44:319-326

4. Berschneider HM, Knowles MR, Azizkhan RG, Boucher RC, Tobey NA, Orlando RC, Powell DW (1988) Altered intestinal chloride transport in cystic fibrosis. FASEB J 2:2625-2629

5. Bijman J, Fromter E (1987) Direct demonstration of high transepithelial chloride conductance in normal human sweat duct which is absent in cystic fibrosis. Pflugers Arch 407 [Suppl 2]: S123-S127

6. Bijman J, Quinton PM (1987) Permeability properties of cell membranes and tight junctions of normal and cystic fibrosis sweat ducts. Pflügers Arch 408:505-510

7. Bijman J, De Jonge HR, Wine J (1988) Cystic fibrosis advantage. Nature 336:430

8. Boucher RC, Stutts MS, Knowles MR, Cantley L, Gatzy JT (1986) $\mathrm{Na}^{+}$transport in cystic fibrosis respiratory epithelia. J Clin Invest $78: 1245-1252$

9. Brock DJH, Clarke HAK, Barron L (1988) Prenatal diagnosis of cystic fibrosis by microvillar enzyme assay on a sequence of 258 pregnancies. Hum Genet 78:271-275

10. Chen JH, Schulman H, Gardner P (1989) A cAMP-regulated chloride channel in lymphocytes that is affected in cystic fibrosis. Science $243: 657-660$

11. Claass AHW, Kleijer WJ, Van Diggelen OP, Van der Veer E, Sips HJ (1986) Prenatal detection of cystic fibrosis; comparative study of maltase and alkaline phosphatase activities in amniotic fluid. Prenat Diagn 6:419-427

12. Cutting GR, Antonarakis SE, Buetow KH, Kasch LM, Rosenstein BJ, Kazazian HH (1989) Analysis of DNA polymorphism haplotypes linked to the cystic fibrosis locus in North American black and Caucasian families supports the existence of multiple mutations of the cystic fibrosis gene. Am J Hum Genet $44: 307-318$

13. De Jonge HR (1984) Cyclic nucleotide-dependent protein phosphorylation in intestinal epithelium. KROC Found Ser $17: 263-286$

14. De Jonge HR, Lohmann SM (1985) Mechanisms by which cyclic nucleotides and other intracellular mediators regulate secretion. Ciba Found Symp 112:116-138

15. De Jonge HR, Bijman J, Sinaasappel M (1987) Relation of regulatory enzyme levels to chloride transport in intestinal epithelial cells. Pediatr Pulmonol [Suppl 1]:54-57

16. De Jonge HR, Bijman J, Sinaasappel M (1988) Application of regulatory principles to CF. Pediatr Pulmonol [Suppl 2]:93-95

17. De Jonge HR, Van den Berghe N, Tilly BC, Kansen M, Bijman J (1989) (Dys)regulation of epithelial chloride channels. Biochem Soc Trans 17:816-818

18. Devoto M, Antonelli M, Bellini F, Borgo G, Castiglione O, Curcio L, Dallapicola B, Ferrari M, Gasparini P, Giunta A, Marianelli L, Mastella G, Novelli G, Pignatti PF, Romano L, Romeo G, Seia M (1988) Rarer alleles of DNA RFLP's closely linked to the CF gene are significantly more frequent in Italian CF patients without pancreatic insufficiency. Am J Hum Genet 43: A82

19. Dorin JR, Novak M, Hill RE, Brock DJH, Secher DS, Van Heyningen V (1987) A clue to the basic defect in cystic fibrosis from cloning the $\mathrm{CF}$ antigen gene. Nature 326:614-617

20. Drumm ML, Smith CL, Dean M, Cole JL, Iannuzzi MC, Collins FS (1988) Physical mapping of the cystic fibrosis region by pulsed-field gel electrophoresis. Genomics 2:346-354

21. Eiberg H, Mohr J, Schmiegelow K, Nielsen LS, Williamson R (1985) Linkage relationships of paraoxonase (PON) with other markers: indication of PON-cystic fibrosis synteny. Clin Genet $78: 265-271$

22. Estivill X, Scambler PJ, Wainwright BJ, Hawley K, Frederick P, Schwartz M, Baiget M, Kere J, Williamson R, Farrall M
(1987) Patterns of polymorphism and linkage disequilibrium for cystic fibrosis. Genomics 1:257-263

23. Estivill X, Farrall M, Scambler PJ, Bell GM, Hawley KMF, Lench NJ, Bates GP, Kruyer HC, Frederick PA, Stanier P, Watson EK, Williamson R, Wainwright BJ (1987a) A candidate for the cystic fibrosis locus isolated by selection for methylation-free islands. Nature 326:840-845

24. Estivill X, Farrall M, Williamson R, Ferrari M, Seia M, Giunta AM, Novelli G, Potenza L, Dallapicola B, Borgo G, Gasparini P, Pignatti PF, De Benedetti L, Vitale E, Devoto M, Romeo $G$ (1988) Linkage disequilibrium between cystic fibrosis and linked DNA polymorphisms in Italian families: a collaborative study. Am J Hum Genet 43:23-28

25. Estivill X, McLean C, Nunes V, Casals T, Gallano P, Scambler P, Williamson R (1989) Isolation of a new DNA marker in linkage disequilibrium with cystic fibrosis, situated between J3.11 (D7S8) and IRP. Am J Hum Genet 44:704-710

26. Farrall M, Estivill X, Williamson R (1987) Indirect cystic fibrosis carrier detection. Lancet II : $156-157$

27. Farrall M, Wainwright BJ, Feldman GL, Beaudet A, Sretenovic Z, Halley D, Simon M, Dickerman L, Devoto $M$, Romeo G, Kaplan J-C, Kitzis A, Williamson R (1988) Recombinations between IRP and cystic fibrosis. Am J Hum Genet $43: 471-475$

28. Feldman GL, Williamson R, Beaudet AL, O'Brien WE (1988) Prenatal diagnosis of cystic fibrosis by DNA amplification for detection of KM-19 polymorphism. Lancet II : 102

29. Fraizer GC, Harrold TR, Hofker MH, Cox DW (1989) Inframe single codon deletion in the Mmalton deficiency allele of a.1-antitrypsin. Am J Hum Genet 44:894-902

30. Goodfellow PN (1989) Steady steps lead to the gene. Nature 341:102-103

31. Greger R (1985) Ion transport mechanisms in thick ascending limb of Henle's loop of mammalian nephron. Physiol Rev 65: 760-779

32. Halley DJJ, Damme NHM van, Deelen WH, Oostra BA, Jahoda MGJ, Sachs ES, Los FJ, Niermeijer MF (1989) Prenatal detection of major cystic fibrosis mutation. Lancet II : 972

33. Hamil OP, Marty A, Neher E, Sackmann B, Sigworth FJ (1981) Improved patch-clamp technique for high resolution current recording from cells and cell free patches. Pflügers Arch 391:85-100

34. Higgins C (1989) Protein joins transport family. Nature 341 : 103

35. Hwang TC, Lu L, Zeitlin PL, Gruenert DC, Huganir R, Guggino WB (1989) $\mathrm{Cl}^{-}$channels in CF: lack of activation by protein kinase $\mathrm{C}$ and $\mathrm{cAMP}$-dependent protein kinase. Science $244: 1351-1353$

36. Iannuzzi MC, Dean M, Drumm ML, Hidaka N, Cole JL, Perry A, Stewart C, Gerrard B, Collins FS (1989) Isolation of additional polymorphic clones from the cystic fibrosis region, using chromosome jumping from D7S8. Am J Hum Genet 44: $695-703$

37. Kartner N, Ling V (1989) Multidrug resistance in cancer. Sci Am (March) : 26-33

38. Kerem B-S, Buchanan JA, Durie P, Corey ML, Levison H, Rommens JM, Buchwald M, Tsui L-C (1989) DNA marker haplotype associations with pancreatic sufficiency in cystic fibrosis. Am J Hum Genet 44:827-834

39. Kerem B-S, Rommens JM, Buchanan JA, Markiewicz, Cox TK, Chakravarti A, Buchwald M, Tsui L-C (1989) Identification of the cystic fibrosis gene: genetic analysis. Science 245 : $1073-1080$

40. Knowles M, Gatzy JT, Boucher RC (1981) Increased bioelectric potential difference across respiratory epithelia in cystic fibrosis. N Engl J Med 305: 1489-1494

41. Knowles M, Spock A, Fischer N, Gatzy JT, Boucher RC (1983) Abnormal ion permeation through cystic fibrosis respiratory epithelium. Science 221:1067-1070

42. Knowlton RG, Cohen-Haguenauer O, Nguyen VC, Frezal J, Brown V, Barker D, Braman JC, Schumm JW, Tsui L-C, 
Buchwald M, Donis-Keller H (1985) A polymorphic DNA marker linked to cystic fibrosis is located on chromosome 7 . Nature 318:380-382

43. Li M, McCann JD, Liedtke CM, Nairn AC, Greengard P, Welsh MJ (1988) Cyclic AMP dependent protein kinase opens chloride channels in normal but not cystic fibrosis epithelium. Nature 331:358-360

44. Li M, McCann JD, Anderson MP, Clancy JP, Navin AC, Greengard P, Welsh MJ (1989) Regulation of chloride channels by protein kinase $C$ in normal and cystic fibrosis airway epithelia. Science $244: 1353-1356$

45. Maciejko D, Bal J, Mazurczak T, Meerman G te, Buys C, Oostra B, Halley D (1989) Different haplotypes for cystic fibrosis-linked DNA polymorphisms in Polish and Dutch populations. Hum Genet 83:220-222

46. Muller F, Oury JF, Dumez Y, Boue J, Boue A (1988) Microvillar enzyme assays in amniotic fluid and fetal tissues at different stages of development. Prenat Diagn 8:189-198

47. Neijens HJ, Sinaasappel M, De Groot R, De Jongste JC, Overbeek SE (1989) Cystic fibrosis, pathophysiological and clinical aspects. Eur J Pediatr (in press)

48. Northrup H, Rosenbloom C, O'Brien WE, Beaudet AL (1989) Additional polymorphism for D7S8 linked to cystic fibrosis including detection by DNA amplification. Nucl Acids Res 17: 1784

49. Poustka A, Lehrach, Williamson R, Bates G (1988) A longrange restriction map encompassing the cystic fibrosis locus and its closely linked genetic markers. Genomics 2:337-345

50. Quinton PM (1983) Chloride impermeability in cystic fibrosis. Nature 301:421-422

51. Quinton PM, Bijman J (1983) Higher bioelectric potentials due to decreased chloride absorption in the sweat glands of patients with cystic fibrosis. N Eng J Med 308:1185-1189

52. Riordan JR, Rommens JM, Kerem B-S, Alon N, Rozmahel R, Grzelczak Z, Zielenski J, Lok S, Plavsic N,Chou J-L, Drumm ML, Iannuzzi MC, Collins FS, Tsui L-C (1989) Identification of the cystic fibrosis gene: cloning and characterization of complementary DNA. Science 245:1066-1073

53. Rommens JM, Kerem B-S, Melmer G, Kennedy D, Plavsic N, Rozmahel R, Markiewicz D, Zsiga M, Riordan JR, Buchwald M, Tsui L-C (1988) Genetic and physical mapping of the chromosomal region containing the cystic fibrosis locus. Am J Hum Genet 43: A199
54. Rommens JM, Iannuzzi MC, Kerem B-S, Drumm ML, Melmer G, Dean M, Rozmahel R, Cole JL, Kennedy D, Hidaka N, Zsiga M, Buchwald M, Riordan JR, Tsui L-C, Collins FS (1989) Identification of the cystic fibrosis gene: chromosome walking and jumping. Science 245:1059-1065

55. Scholte BJ, Kansen M, Hoogeveen AT, Willemse R, Rhim JS, Kamp AWM van der, Bijman J (1989) Immortalization of nasal polyp epithelial cells from cystic fibrosis patients. Exp Cell Res 182:559-571

56. Schoumacher RA, Shoemaker RL, Halm DR, Talent EA, Wallace RW, Frizzell RA (1987) Phosphorylation fails to activate chloride channels from cystic fibrosis airway cells. Nature $330: 752-754$

57. Shoemaker RL, Frizzell RA, Dwyer TM, Farley JM (1986) Single chloride channel currents from canine tracheal epithelial cells. Biochim Biophys Acta 858:235-243

58. Spence MA, Tsui L-C (1987) Report of the committee on the genetic constitution of chromosomes 7,8 and 9 . Cytogenet Cell Genet 46:170-187

59. Valerio D, Van Beusechem VW, Einerhand MP, Hoogerbrugge PM, Van der Putten H, Wamsley PM, Berkvens TM, Verma IM, Kellens RE, Van der Eb AJ, Van Bekkum DW (1988) Towards gene therapy for adenosine deaminase deficiency. In: Baum SJ, Dicke KA, Lotzova E, Pluznik DH (eds) Experimental hematology today. Springer, Berlin Heidelberg New York Tokyo, pp 92-98

60. Wainwright BJ, Scambler PJ, Schmidtke J, Watson EA, Law H-Y, Farrall M, Cooke HJ, Eiberg H, Williamson R (1985) Localization of the cystic fibrosis locus to human chromosome 7. Nature 318:384-385

61. White R, Woodward S, Leppert M, O'Connell P, Nakamura Y, Hoff M, Herbst J, Lalonel J-M, Dean W, Vande Woude G (1985) A closely genetic linked marker for cystic fibrosis. Nature 318:282-384

62. Williams C, Williamson R, Coutelle C, Loeffler F, Smith J, Ivinson A (1988) Same-day, first trimester antenatal diagnosis for cystic fibrosis by gene amplification. Lancet II : 102-103

63. Willumsen NJ, Boucher RC (1989) Activation of an apical $\mathrm{Cl}^{-}$ conductance by $\mathrm{Ca}^{2+}$ ionophores in cystic fibrosis airway epithelia. Am J Physiol 256:C226-C233 